\title{
Exploitation of gamma delta T cells in cancer immunotherapy as combined antigen-presenters and cancer cell killers
}

\author{
Gitte Holmen Olofsson ${ }^{1 *}$, Manja Idorn', Wajid Khan², Mads Hald Andersen ${ }^{1}$, Bernhard Moser ${ }^{2}$, Per thor Straten ${ }^{1}$ \\ From Society for Immunotherapy of Cancer 29th Annual Meeting \\ National Harbor, MD, USA. 6-9 November 2014
}

The human $\mathrm{V} \gamma 9 \mathrm{~V} \delta 2 \mathrm{~T}$ cells are a unique $\mathrm{T}$ cell type, and recent studies of the biology of $\mathrm{V} \gamma 9 \mathrm{~V} \delta 2 \mathrm{~T}$ cells emphasize the potential exploitation of these cells in immunotherapy of cancer. $\mathrm{V} \gamma 9 \mathrm{~V} \delta 2 \mathrm{~T}$ cells exhibit dual functionality in that they are both antigen-presenting cells and cytotoxic towards cancer cells. We have been able to show that $\mathrm{V} \gamma 9 \mathrm{~V} \delta 2 \mathrm{~T}$ cells can kill cancer cells from various cancer types such as breast cancer, leukemia cancer lines and malignant melanoma, with a significantly increased killing upon treatment of the cancer cells with Zoledronic acid. In addition, cross presentation of antigens was also confirmed by using flow cytometry and chromium release assays. Furthermore, $\mathrm{V} \gamma 9 \mathrm{~V} \delta 2 \mathrm{~T}$ cells were also able to induce a conventional CMV-specific $\alpha \beta$-T cells response/culture. Unique to these findings is that it is the same $\gamma \delta \mathrm{T}$ cells that exhibit both functionality as APC and cancer killers. This combined with the ease of expanding $\mathrm{V} \gamma 9 \mathrm{~V} \delta 2 \mathrm{~T}$ cells in vitro to billions of cells, makes $\mathrm{V} \gamma 9 \mathrm{~V} \delta 2 \mathrm{~T}$ cells an attractive alternative to conventional antigen-presenting cells, such as dendritic cells. Moreover, a cell that kills tumor targets and concurrently induces a response against the tumor cell it kills, holds great potential for clinical use. We are currently setting up in vivo experiments using the NOG mouse model to study the in vivo capacity of $\mathrm{V} \gamma 9 \mathrm{~V} \delta 2 \mathrm{~T}$ cells to delay tumor growth.

\section{Authors' details \\ ${ }^{1}$ Center for Cancer Immune Therapy, Herlev, Denmark. ${ }^{2}$ Cardiff Institute of Infection \& Immunity, Cardiff CF14 4XN, United Kingdom.}

Published: 6 November 2014

${ }^{1}$ Center for Cancer Immune Therapy, Herlev, Denmark

Full list of author information is available at the end of the article
doi:10.1186/2051-1426-2-S3-P18

Cite this article as: Holmen Olofsson et al:: Exploitation of gamma delta $T$ cells in cancer immunotherapy as combined antigen-presenters and cancer cell killers. Journal for ImmunoTherapy of Cancer 2014 2(Suppl 3): P18.
Submit your next manuscript to BioMed Central and take full advantage of:

- Convenient online submission

- Thorough peer review

- No space constraints or color figure charges

- Immediate publication on acceptance

- Inclusion in PubMed, CAS, Scopus and Google Scholar

- Research which is freely available for redistribution

Submit your manuscript at www.biomedcentral.com/submit
() Biomed Central 